J. Perinat. Med. 9 (1981) 141

\title{
$\beta$-Thromboglobulin levels in plasma of jaundiced neonates exposed to phototherapy
}

\author{
M. A. G. Karim, I. A. Clelland, I. V.Chapman, C. H. M. Walker \\ Departments of Medical Biophysics and Paediatrics, University of Dundee
}

MAURER et al. [2] reported changes in human platelets when platelet rich plasma was exposed to fluorescent light for $110 \mathrm{~min}$, irradiance $10.8 \mathrm{~W} /$ $\mathrm{m}^{2} / \mathrm{sec}$ at $460 \mathrm{~nm}$. A significant loss of ability to aggregate when challenged with Adenosine di Phosphate (ADP) was observed, and platelet turnover was significantly increased when both rabbits and low birthweight infants were irradiated continuously for $96 \mathrm{hrs}$ [3].

Recent studies by KARIM [1] suggest that platelet rich plasma from adult volunteers exposed both in the presence and absence of bilirubin to light of irradiance $3.5 \mathrm{~W} / \mathrm{m}^{2} / \mathrm{sec} 450 \mathrm{~nm} \pm 42 \mathrm{~nm}$ for 60 $\min$ at $37^{\circ} \mathrm{C}$, did not cause any significant platelet damage as asssssed by the $\beta$-thromboglobulin ( $\beta$-T G) release reaction.

The present study seeks to answer the question whether exposure of jaundiced neonates to phototherapy injures the platelet as assessed by $\beta-T$ G levels in platelet poor plasma after treatment. Possible artifacts which may influence the interpretation of the $\beta$-T $\mathrm{G}$ levels are also considered.

\section{Materials and method}

Two banks of phototherapy lamps in current clinical use were calibrated for this study using a spectral radiometer: (i) Seven OSRAM $02041120 \mathrm{~W}$ Daylight lamps, irradiance $2 \mathrm{~W} / \mathrm{m}^{2} / \mathrm{sec}$ at $30 \mathrm{cms}$ in the spectral range $450 \mathrm{~nm} \pm 42 \mathrm{~nm}$. (ii) Four 'Blue' light lamps, PHILIPS TL $20 \mathrm{~W} / 03 \mathrm{~T}$, irradiance value $3.5 \mathrm{~W} / \mathrm{m}^{2} / \mathrm{sec}$ at $30 \mathrm{cms}$ in spectral range $450 \mathrm{~nm} \pm 42 \mathrm{~nm}$.

Cord blood was collected directly by free flow and/or gentle milking into plastic containers which were placed in a crushed ice-water mixture for ten minutes for rapid cooling. Adult venous blood was similarly cooled having

\section{Curriculum vitae}

IAN V. CHAPMAN, M.R.S.C., C. CHEM., Ph. D. initially qualified in chemistry before studying biochemistry. He carried out research leading to the degree of Doctor of Philosophy in Newcastle, England. The thesis was entitled 'Radiation effects on some enzyme systems'. He was appointed at University of

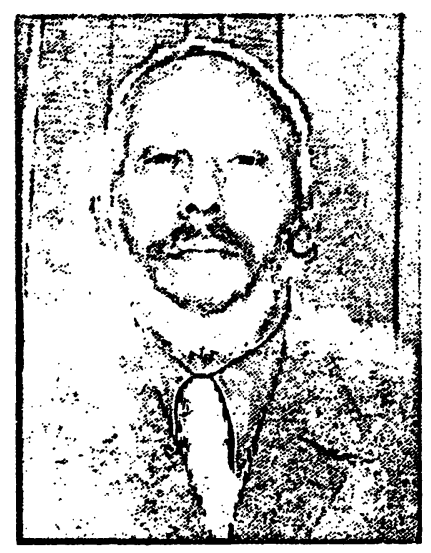
Dundee in 1969 and holds the post of Senior Lecturer in the Department of Medical Biophysics together with an honorary Senior Medical Physicist post with the Tayside Health Board.

been collected in a plastic syringe using a $20 \mathrm{G}$ needle and transferred to plastic containers. These samples were divided and to one half bilirubin was added to a final concentration of $340 \mu \mathrm{M} / \mathrm{L}$ before exposure to light (BANK [ii] for $60 \mathrm{mins}$ at $37^{\circ} \mathrm{C}$ ).

Subsequently each half sample was again divided into two parts; of the two with bilirubin added, one was exposed to phototherapy, whilst the other was shielded with foil: One of the other two specimens was exposed and the other shielded. Following exposure, $0.1 \mathrm{ml}$ antiplatelet anticoagulant (ethylene diamine tetra-acetic acid (EDTA) of final concentration $1 \mathrm{mM} / \mathrm{L}$, plus theophylline of final concentration $3 \mathrm{mM} / \mathrm{L}$ was added to each specimen.

Blood $(0.5 \mathrm{ml})$ was obtained from the babies by heel prick and immediately transferred to plastic tubes in crushed ice-water, each containing $0.1 \mathrm{ml}$ anti-platelet anticoagulant. This was a volume suited to the smaller volume of blood. Twelve jaundiced neonates (serum bilirubin level 204-238 $\mu \mathrm{M} / \mathrm{L}$ ) had their samples taken before and after continuous exposure to BANK [i] lamps for $24-120 \mathrm{hr}$ periods.

Having been again cooled in crushed ice-water for 1-2 mins the samples were centrifuged at $1500-2000 \mathrm{~g}$ at 
$4{ }^{\circ} \mathrm{C}$ for 30 mins. The platelet-poor plasma was then taken off and assayed for $\beta-T, G$ by adding 50 microlitres to 200 microlitres of ${ }^{125}$ I labelled $\beta-T$ G plus 200 microlitres of anti $\beta-T$ G serum. The sample was vortexed and incubated for one hour at room temperature. Subsequently 500 microlitres of ammonium sulphate solution ( $\beta-T$ G kit supply) was added and the mixture again vortexed. After centrifuging for 10-15 mins at $1000-1500 \mathrm{~g}$ the supernatant was removed and the radio-activity of the precipitate determined by $\gamma$-scintillation counting.

\section{Results}

There was no significant difference in $\beta$-T G levels of platelet poor plasma following exposure of whole blood to bilirubin alone or bilirubin plus light (Tab. I). Similar negative results were obtained with adult venous blood (Tab. I).

There was no indication of significant platelet destruction when the $\beta$-TG levels in non-jaundiced and jaundiced babies before and after phototherapy were compared (Tab. II).

\section{Discussion}

$\beta$-T $G$ release studies failed to reveal damage to newborn or adult platelets which had been exposed to phototherapy in the presence of physiological levels of bilirubin, or to the bilirubin alone (Tab. I). It must be admitted, however, that neither the work of MAURER [2] nor the present

Tab. I. $\beta$-thromboglobulin content of platelet-poor plasma prepared from cord blood and adult venous blood.

\begin{tabular}{|c|c|c|c|c|c|c|}
\hline \multirow[b]{3}{*}{ Sample } & \multicolumn{6}{|c|}{$\beta$-Thromboglobulin content of plasma } \\
\hline & \multicolumn{3}{|c|}{ From Cord Blood } & \multicolumn{3}{|c|}{ From Adult Blood } \\
\hline & $\mathrm{ng} / \mathrm{ml} \pm$ S.D. & $\begin{array}{l}\text { No. of } \\
\text { observations }\end{array}$ & $\mathbf{p}$ & $\mathrm{ng} / \mathrm{ml} \pm$ S.D. & $\begin{array}{l}\text { No. of } \\
\text { observations }\end{array}$ & $\mathbf{p}$ \\
\hline Control & $404 \pm 12$ & 10 & & $156 \pm 68$ & 10 & \\
\hline Phototherapy only & $395 \pm 1$ & 10 & $>0.5$ & $140 \pm 65$ & 10 & $>0.5$ \\
\hline Bilirubin only* & $404 \pm 20$ & 10 & $>0.1$ & $175 \pm 109$ & 10 & $>0.5$ \\
\hline $\begin{array}{l}\text { Bilirubin plus* } \varphi \\
\text { phototherapy }\end{array}$ & $417 \pm 7$ & 10 & $>0.5$ & $170 \pm 76$ & 10 & $>0.5$ \\
\hline
\end{tabular}

* Bilirubin added to level of $340 \mu \mathrm{M} / \mathrm{L}$.

$\varphi$ Exposure to lamp bank (ii) for one hour.

Tab. II. Comparison of $\beta$-thromboglobulin levels in platelet-poor plasma prepared from samples taken from jaundiced babies before and after phototherapy and from non-jaundiced babies.

\begin{tabular}{lll}
\hline Sample & $\begin{array}{l}\text { No. of } \\
\text { Observa- } \\
\text { tions }\end{array}$ & $\begin{array}{l}\beta-\mathrm{T} \mathrm{G} \mathrm{ng/ml} \\
\text { Mean } \pm \text { S.D. }\end{array}$ \\
\hline $\begin{array}{l}\text { Non-jaundiced babies } \\
\begin{array}{l}\text { Jaundiced babies } \\
\text { Pre-phototherapy }\end{array}\end{array}$ & $12 *$ & $138 \pm 20$ \\
$\begin{array}{l}\text { Jaundiced babies } \\
\text { Post-phototherapy }\end{array}$ & 12 & $134 \pm 35$ \\
\hline
\end{tabular}

* 2 each from 6 babies

$\mathrm{p}->0.5$ comparing all 3 groups in vitro study exactly represents the clinical situation. In the former the irradiance used $\left(10.8 \mathrm{~W} / \mathrm{m}^{2}\right.$ / sec) was about three times that which is used clinically and the tests were performed at a non-physiological $\mathrm{pH}$ (7.7). Exposure times were however similar to those used clinically. In the present studies the irradiance was similar to that encountered clinically $\left(2-3.5 \mathrm{~W} / \mathrm{m}^{2} / \mathrm{sec}\right)$ and the tests were carried out at a physiological $\mathrm{pH}(7.3-7.4)$ but the time of exposure was shorter ( $60 \mathrm{mins})$. These differing factors could well account for the different results obtained from the two studies and the present technique is worthy of repetition with longer periods of exposure. 
An explanation of the finding that adult $\beta-T$ G values in this study were higher than those reported elsewhere [4] may be that the assay methods differed considerably and the platelets in this study had been exposed to $60 \mathrm{~min}$ incubation at $37{ }^{\circ} \mathrm{C}$ before preparation of the platelet poor plasma. Likewise the $\beta-T$ G levels in cord blood were 2-3 times higher than those of the adults in this study.

This might reflect the higher platelet content of cord blood and the trauma of the gentle "milking" collection technique. The higher levels in the newborn could also be due to trauma of the heelprick collection method.

However, these higher levels do not nullify the significance of the data presented especially since the non-jaundiced and pre- and post-phototherapy jaundiced baby values are obtained in circumstances truly representative of the clinical treatment situation.

\section{Summary}

It has been suggested that changes take place in human platelets when they are exposed to fluorescent light of $10.8 \mathrm{~W} / \mathrm{m}^{2} / \mathrm{sec}$ at $460 \mathrm{~nm}$. Loss of ability to aggregate and increase in turnover rate have been reported. However, studies of the effect of fluorescent light on adult platelets when exposed to the level of irradiance used clinically $\left(3.5 \mathrm{~W} / \mathrm{m}^{2} / \mathrm{sec}\right)$ for $60 \mathrm{~min}$ did not reveal this effect. A study was therefore designed to compare the effects of bilirubin and phototherapy alone and in combination on cord and adult blood platelets and to test the effect of this lower range of irradiance on platelets obtained from jaundiced neonates.
Using $\beta$-thromboglobulin as the indicator of platelet damage, no significant change was found in platelet poor plasma from cord or adult blood following exposure to bilirubin and/or light, nur was any change found in the plasma of jaundiced neonates before and after therapy. Although the duration of exposure to light in this study was short, the results suggest that the lower levels of irradiance used clinically are not harmful to platelets and that the results of studies done with three times as much irradiance have little clinical relevance.

Keywords: $\beta$-Thromboglobulin, jaundiced neonates, phototherapy, platelet damage.

\section{Zusammenfassung}

$\beta$-Thromboglobulin-Spiegel im Plasma von ikterischen Neugeborenen unter Phototherapie

Es gibt Hinweise dafür, daß humane Thrombozyten sich unter Bestrahlung mit fluoreszierendem Licht mit einer Stärke von $10,8 \mathrm{~W} / \mathrm{m}^{2} / \mathrm{sec}$ bei $460 \mathrm{~nm}$ verändern. Aggregationshemmung und erhöhte Turn-over wurden beschrieben.

Fluoreszierendes Licht mit einer Bestrahlungsdosis von $3,5 \mathrm{~W} / \mathrm{m}^{2} / \mathrm{sec}$ über 60 Minuten hatte keinen Einfluß auf die Thrombozyten bei Erwachsenen. Deshalb wurde eine Studie angelegt, in der der Einfluß von Bilirubin und Phototherapie ie getrennt und in Kombination auf die Thrombozytenfunktion aus Nabelschnur- und Erwachsenen blut untersucht wurde.

Ebenfalls wurde der Einfluß von niedrigdosierten fluoreszierenden Strahlen auf den Thrombozy ten von ikterischen
Neugeborenen untersucht. Mit dem $\beta$-Thromboglobulin als Indikator für den Thrombozy tenschaden wurden keine signifikanten Veränderungen gefunden, sowohl im bilirubininkubierten als auch im strahlenausgesetzten thrombozytenarmen Plasma, gewonnen aus Erwachsenen- und Nabelschnurblut. Auch wurden keine Veränderungen festgestellt im Plasma von ikterischen Neugeborenen vor und nach der Therapie.

Obwohl die Bestrahlungszeit in dieser Studie kurz war, lassen die Ergebnisse vermuten, daß eine niedrige therapeutische Bestrahlungsdosis keine Einwirkungen auf die Thrombozyten hat und daß die Ergebnisse in Studien mit der 3-fachen Bestrahlungsdosis nicht relevant sind. 


\section{Résumé}

La concentration de $\beta$-thromboglobulin dans le plasma des nouveau - nés atteint de jaunisse et soumis à la photothérapie

Il a été suggeré que les plaquettes humaines se transforment lorsqu'elles sont exposées à une lumière fluorescente de $10,8 \mathrm{~W} / \mathrm{m}^{2} / \mathrm{sec}$ à $460 \mathrm{~nm}$.

Un arrêt d'aggrégation et un renouvellement plus rapide ont été décrit. Une lumière fluorescente avec une dose de radiation de $3,5 \mathrm{~W} / \mathrm{m}^{2} / \mathrm{sec}$ durant 60 minutes n'avait pás d'influence sur les plasquettes de l'adulte. Une étude comparative des effets de la bilirubine et de la photothérapie sul et combinée, a été effectué sur la fonction plaquettaire du cordon ombilical et du sang de l'adulte en vue de tester l'effet, d'une dose de radiation plus basse, sur les plaquettes de nouveau - nés ayant la jaunisse.
Une estimation de dégâts iplaquettaires à l'aide de la $\beta$ thromboglobulin n'a pas donné de changement significatif dans le plasma de l'ombilic et du sang de l'adulte exposé à la bilirubine et/ou à la lumière.

De sorte qu'il n'y a pas de changement dans le plasma des nouveau - nés ayant la jaunisse, avant et après le traitement.

Qui que la durée de l'exposition à la lumière lors de cette étude ait été brève, il semblerait que l'usage clinique de faibles doses de radiation soit sans danger pour les plaquettes.

Le résultat des études avec une dose de radiation trois fois plus forte est sans conséquence vu qu'elle ne relève pas du domaine clinique.

Mots-clés: $\beta$-thromboglobulin, dégât plaquettaire, la jaunisse de nouveau - né, photothérapie.

\section{Bibliography}

[1] KARIM, M. A. G.: Investigation of blood cell modification induced by photo-oxidation of bilirubin in human blood. M. Sc. Thesis, University of Dundee 1978

[2] MaUrer, H. M., J. C. HAggins, W. J. S. Still: Platelet injury during phototherapy. Amer. J. Hematol. 11 (1976) 89

[3] MAURER, H. M., M. FRATKIN, N.B.MCWILLIAMS, B. KIRPARTRICK, D. DRAPER, J. C. HAGGINS,
C. R. HUNTER: The effect of phototherapy on platelet count in low birth weight infants and on platelet production and life span in rabbits. Pediatrics 57 . (1976) 506

[4] The Radiochemical Centre $\beta$-thromboglobulin radioimmunoassay kit booklet. Amersham, Bucks., England

Received November 3, 1980. Revised January 29, 1981. Accepted March 25, 1981.

I. V. Chapman

Department of Medical University

Perth Road, Dundee, DD1 4HN.

Tel. No. (0382) 23181, Ext. 506 